\title{
Najnowsze publikacje Muzeum Historii Polskiego Ruchu Ludowego
}

\author{
The Latest Publications \\ of Muzeum Historii \\ Polskiego Ruchu Ludowego
}

\section{Wprowadzenie}

W ostatnim czasie nastąpiła znaczna intensyfikacja działalności wydawniczej Muzeum Historii Polskiego Ruchu Ludowego (MHPRL). Placówka ta, obok klasycznej dla muzeów działalności zbierania, opracowywania i udostępniania wszelkich materiałów związanych z dziejami ruchu społecznego (politycznego, kulturalnego), prowadzi wartą szczególnego docenienia działalność wydawniczą. Dzięki podjęciu szeregu wyzwań edytorskich stała się ośrodkiem integrującym szerokie rzesze naukowców oraz zasłużonych działaczy tego z gruntu patriotycznego ruchu. Wydawnicza aktywność muzealna powiązała obie te grupy z sobą w sposób niejako komplementarny. Dlatego działacze, animatorzy życia społeczno-kulturalnego i politycznego dawnej wsi oraz naukowcy, szczególnie powojennych pokoleń (po II wojnie światowej), mogą niejako wspólnie, chociaż w ramach osobnych publikacji, budować zobiektywizowany obraz historii ruchu ludowego, wsi i regionów oraz państwa.

Ukierunkowanie aktywności muzealnej w dziedzinie wydawniczej wyraźnie nastąpiło z chwilą objęcia funkcji dyrektora tej placówki przez dr. Janusza Gmitruka (od 1997 r.), także jednocześnie dyrektora Zakładu Historii Ruchu Ludowego (ZHRL) przy Naczelnym Komitecie Polskiego Stronnictwa Ludowego (NK PSL) (od I990) i prezesa Ludowego Towarzystwa Naukowo-Kulturalnego (LTN-K). Trudno nie docenić Jego roli jako inspiratora, redaktora i autora publikacji muzealnych. Mając efektywne poparcie władz samorządowych woj. mazowieckiego i osobiście marszałka dr. Adama 
Struzika, (Muzeum jest jednostką organizacyjną Samorządu Województwa Mazowieckiego), uczynił z MHPRL czołowy ośrodek upowszechniania wiedzy o historycznych i współczesnych dokonaniach ruchu ludowego. Ośrodek ten, prowadząc działalność wydawniczą, wytycza kolejne kierunki zainteresowań badawczych i popularyzatorskich, istotnie wzbogacających świadomość historyczną współczesnych pokoleń Polaków; przynajmniej tej części naszego społeczeństwa w większości wywodzącego się ze wsi, jeśli nie w pierwszej, to na pewno w kolejnych generacjach, żyjącego i w mieście, i na wsi, które nie musi się wstydzić swojego pochodzenia.

Polski ruch ludowy może się poszczycić wieloma postaciami sztandarowymi, wybitnymi i istotnie ważącymi na dziejach państwa. Biografie takich mężów stanu, jak Wincenty Witos, Maciej Rataj, Stanisław Mikołajczyk i wielu innych, doczekały się licznych kompetentnych opracowań. Lecz warto też uświadomić sobie, że i działacze szczebla niższego, tego chłopskiego ze swej istoty ruchu społecznego, wnieśli swoje zasługi, wypracowane nie tylko na szczeblu centralnym, ale choćby w regionie, na rzecz sprawiedliwości społecznej, kultury i wzrostu gospodarczego „małych ojczyzn”, czyli w sumie kraju. Również ich życiorysy i wkład w rozwój społeczno-gospodarczy zasługują na szczególne docenienie, co zresztą Muzeum akcentuje swoją aktywnością wydawniczą, z pożytkiem dla budowania świadomości historycznej naszego społeczeństwa.

Wszystkie publikacje muzealne cechuje wysoki poziom edytorski i atrakcyjna dla czytelnika szata graficzna. Są bardzo starannie redagowane pod względem formalno-technicznym przez mgr Dorotę Pasiak-Wąsik (kier. Działu Naukowego), nieocenioną w tym względzie.

Udostępnienie kolejnych publikacji następuje po organizowanych publicznie promocjach, zazwyczaj połączonych z sesjami naukowymi (zwykle przy współudziale TN-K i ZHRL), z udziałem autora, który ma okazję na przedstawienie swojego dzieła. Podczas tych spotkań dyskusję kompetentnie aranżuje dr Ryszard Miazek (kier. Działu Oświatowo-Naukowego).

Poniżej przedstawię, w postaci zwięzłych prezentacji, najnowsze, choć tylko niektóre efekty jakże pożytecznej w każdym względzie aktywności wydawniczej MHPRL'.

I Na osobną recenzję zasługuje cykl monumentalnych publikacji poświęconych Czesławowi Wycechowi: I) J. Gmitruk, S.J. Pastuszka, R. Turkowski, Czestaw Wycech - nauczyciel, ludowiec, polityk (I899-1977), Warszawa-Kielce-Pińczów 2018; 2) Cz. Wycech, Dzienniki (I864-1967), cz. I, Wprowadzenie: J. Gmitruk, S.J. Pastuszka, R. Turkowski, Warszawa-Kielce-Pińczów 20I8; 3) Cz. Wycech, Dzienniki (Ig68-197I), cz. II, Wprowadzenie: J. Gmitruk, S.J. Pastuszka, R. Turkowski, Warszawa 2019). Ponadto, w niniejszym tomie „Zeszytów Wiejskich” ukazuje się recenzja pracy Janusza Gmitruka, Ludowcy w walce o niepodlegtość, Warszawa 2019, autorstwa prof. Marka Białokura z Uniwersytetu Opolskiego. 
Prezentowaną książkę należy zaliczyć do najważniejszych osiągnięć edytorskich MHPRL, przygotowanych dla uczczenia stulecia odzyskania przez Polskę niepodległości. Jest to rzecz w pełni naukowa, autorstwa historyka posiadającego spory już dorobek publikacyjny i jednocześnie czołowego animatora ruchu ludowego, przy tym ściśle związanego z Mazowszem. Autor urodził się we wsi Soboklęszcz (pow. ciechanowski) w rodzinie chłopskiej. Niejako więc w sposób naturalny związał się z chłopskim ruchem politycznym. Był między innymi pracownikiem naukowym ZHRL przy NK ZSL, zastępcą dyrektora ds. naukowych w Głównej Komisji Ścigania Zbrodni Przeciwko Narodowi Polskiemu - Instytucie Pamięci Narodowej. Pracując pod kierunkiem wybitnego badacza dziejów polskiego ruchu ludowego, prof. Józefa R. Szaflika, zagadnienie: Wieś mazowiecka w okresie II Rzeczypospolitej uczynit przedmiotem pracy doktorskiej obronionej w 1978 r. w Uniwersytecie Warszawskim (Uw). Po dodatkowych kwerendach archiwalnych i uwzględnieniu najnowszej literatury oraz wzmocnieniu własnymi dojrzałymi refleksjami, mógł je rozwinąć i zawrzeć w przedstawionym tutaj, potężnym objętościowo dziele o wsi mazowieckiej.

Pierwszej, bardzo pozytywnej oceny dzieła J. Sałkowskiego, dokonał w Przedmowie Marszałek Województwa Mazowieckiego dr Adam Struzik, wyrażając w pełni uzasadniony treścią książki pogląd, ważny dla oceny znaczenia ruchu ludowego po przewrocie majowym w ramach państwa już autorytarnego: „W tych szczególnie trudnych warunkach, gdy cała antysanacyjna opozycja została wyeliminowana z sejmu i senatu, główną polityczną siłą wyrażającą postawy większości społeczeństwa nie tylko na Mazowszu, ale w ogóle w kraju, stawał się ruch ludowy. Posiadał bowiem najbardziej powszechne zaufanie, cieszących się autorytetem przywódców oraz akceptowany program zmian ustrojowych. Jednak głównym źródłem jego siły było to, że skupiał się przede wszystkim wokół rozwiązywania problemów nurtujących środowiska lokalne. Szczególną płaszczyznę jego aktywności stanowił samorząd terytorialny, w którym u schyłku II Rzeczypospolitej na mazowieckiej wsi - jak ustalił Autor tej książki - sanacja nie znajdowała szerszego oparcia" (s. 9-10).

Układ pracy jest logiczny i przejrzysty, chronologiczno-rzeczowy. Autor konsekwentnie realizuje zasadniczy cel swojego dzieła, czyli, „przedstawienie obrazu wsi mazowieckiej w ujęciu dynamicznym w okresie Drugiej Rzeczypospolitej” (s. II). Na całość składa się głównie sześć rozdziałów merytorycznych. Poprzedzone zostały Wstępem, który zwięźle określił nie tylko cel pracy, ale też źródła, stan badań i założenia metodologiczne. 
Przedmiot badań umiejscowił Autor na „terytorium [które - przyp. A.L.] wchodziło w skład przedwojennego Mazowsza. [...] Otóż jest to przedwojenne województwo warszawskie, którego granice administracyjne uległy istotnym korektom pod koniec lat trzydziestych. Warszawa - stolica państwa, chociaż niezwykle silnie oddziaływała, nie tylko gospodarczo i politycznie, na sąsiednie powiaty, a na jej terenie znajdowały się siedziby mazowieckich urzędów, sama była wyłączona poza opisywany obszar jako województwo grodzkie" (s. I2-I3). Pod względem gospodarczym był to obszar sytuujący się wśród województw typu rolniczego. Natomiast w układach stratyfikacji społecznej był przede wszystkim chłopski, z dużą liczbą pracowników najemnych zatrudnionych w rolnictwie. Na górze tak zwanej drabiny społecznej sytuowała się nieliczna grupa ziemian, właścicieli wielkoobszarowych folwarków. Ponadto w rolnictwie Autor wymienił warstwę społeczną, którą umiejscawia pomiędzy ziemiaństwem a chłopstwem - „liczną na przedwojennym Mazowszu szlachtę”. Jest to nieco ryzykowne wobec kształtowania się w państwie, już nie feudalnym, a liberalno-demokratycznym, nowoczesnej struktury społeczno-zawodowej. Grupa ta mogła siebie z wyższością określać jako szlachta, dysponując odpowiednią dokumentacją herbową z okresu I Rzeczypospolitej, ale w rzeczywistości należała już do tej samej warstwy co chłopi/rolnicy.

Pierwszy z rozdziałów merytorycznych (Rozdz. I Mazowsze w okresie Drugiej Rzeczypospolitej - spoteczeństwo i gospodarka), zresztą najobszerniejszy, określa tło niezbędne do formułowania kolejnych kwestii, przede wszystkim politycznych. Dlatego jeszcze nie odniósł się do wydarzeń z kampanii wyborczych, działalności partii politycznych i w ogóle urzędów w rodzącym się państwie, liberalno-demokratycznym do przewrotu majowego z 1926 r., a później autorytarnym, do zakończenia swego dość krótkiego żywota we wrześniu 1939 r.

W tej części pracy, opartej głównie na opracowaniach i źródłach zastanych (m.in. drukowanych) uzyskamy kompetentne informacje o podziale administracyjnym woj. warszawskiego, samorządzie terytorialnym, strukturze społecznej i zawodowej, gospodarce (przemysł, rolnictwo) oraz zagadnieniach społeczno-kulturalnych (oświata, organizacje społeczne, w tym związki młodzieży wiejskiej, autorytety wiejskie).

Od rozdziału II (Realia spoteczno-polityczne na wsi mazowieckiej I9I8-1930) odnaleźć można w pracy szczegółową analizę wydarzeń politycznych i aktywności w nich partii politycznych różnych ruchów społeczno-politycznych Polaków. Jednakowoż najwięcej uwag zostaje poświęconych partiom i organizacjom społecznym ruchu ludowego, który jako naturalny reprezentant polityczny wsi polskiej, jak się mogło wydawać, powinien mieć największe wpływy na rolniczym Mazowszu. Niemniej jednak, nawet w najlepszych dla ruchu ludowego wyborach parlamentarnych z listopada 
I922 r. partie chłopskie na Mazowszu uzyskały sześć mandatów poselskich (19,4\%) przy dziewiętnastu mandatach (61,3\%) endeckiego Chrześcijańskiego Związku Jedności Narodowej.

Rozdział III (W cieniu wyborów „brzeskich”) opisuje życie polityczne wsi mazowieckiej w końcu lat 20. XX w., w czasach gasnącej demokracji i przechodzenia do autorytarnych rządów wykreowanej po przewrocie majowym tak zwanej sanacji. Zwraca uwagę nie tylko na odsunięcie ludowców jednoczących się w I93I r. w jedna partię polityczną (SL) od udziału w parlamentaryzmie, ale też narażonych na ataki kleru i całej władzy administracyjnej tego województwa.

Rozdział IV (Ewolucja postaw politycznych wsi w latach 1932-1934) przedstawia aktywność ruchu ludowego na rzecz ratowania demokracji i jednocześnie wychodzenia z niedogodności społeczno-gospodarczych spowodowanych wielkim kryzysem ekonomicznym. Ponadto, szczegółowo informuje o: „dążeniach komunistycznej agentury do zrewoltowania wsi”, szczególnie w odniesieniach do młodzieży „wiciowej”; wpływach endeckich („miedzy Obozem Wielkiej Polski a Obozem Narodowo-Radykalnym”) we wsi mazowieckiej; zapędach sanacji w opanowaniu wszystkich dziedzin życia społeczno-gospodarczego, w tym samorządów, o które szczególnie, mniej lub bardziej efektywnie, ruch ludowy zabiegat.

Rozdział v (Wobec autorytarnego państwa) zawiera kolejne szczegółowe analizy działalności ludowców na rzecz ratowania demokracji, szczególnie podczas wyborów parlamentarnych z $1935 \mathrm{r}$. - „między głosowaniem a bojkotem" i w ogóle podczas pozaparlamentarnej aktywności SL. W tej części pracy, zgodnie z pluralistycznym ujęciem treści narracji, znalazło się miejsce na opisanie w kolejności „obozu sanacji w środowiskach wiejskich po dekompozycji”, „Stronnictwa Narodowego w latach 1935-1937” oraz „nowej ofensywy komunistów - «Frontu Ludowego»”.

Rozdział vi (Przed wybuchem II wojny światowej) spina swoistą klamrą narracyjną działalność lewicowych i centrolewicowych, nastawionych opozycyjnie wobec sanacji ruchów politycznych działających na wsi mazowieckiej. Eksponuje przy tym wagę aktywności ruchu ludowego jako wyjątkowo dojrzałego politycznie z punktu widzenia zintegrowanego interesu społeczeństwa i państwa.

SL, po tragicznych doświadczeniach krwawo stłumionego strajku chłopskiego z sierpnia 1937 r., sprawę przywrócenia w Polsce liberalno-demokratycznej formy sprawowania rządów odłożyło na plan dalszy. O tej decyzji zaważyły wcale nie doraźne interesy polityczne, lecz troska o losy ojczyzny, której niepodległość zagrożona była agresją III Rzeszy, wyraźnie już po marcu 1939 r., czyli po zajęciu Czech i Moraw przez wojska niemieckie. 
Wymieniona dojrzałość polityczna spowodowała porzucenie myśli o nowym strajku chłopskim i doprowadziła do ustalenia, że jednak obrona niepodległości stanowi „cel nadrzędny” wszelkiej aktywności ludowców. Odnosząc się do specyficznej sytuacji Mazowsza, Autor przekonująco uzasadnia pogląd, nawiązując zresztą do myśli Wincentego Witosa („Polska będzie żyć wiecznie”), że nawet lewicowo i opozycyjnie nastawione ruchy polityczne Polaków, w tym szczególnie ruch ludowy, mogły zawiesić antyrządowe akcje polityczne, a skupić się na przygotowaniach do obrony niepodległości.

Prezentowaną książkę syntetycznie wieńczy Zakończenie. Przedstawia ono wielowątkowe społeczno-kulturalne, ale przede wszystkim polityczne przejawy życia zorganizowanego pluralistycznie społeczeństwa przedwojennego województwa warszawskiego. Zwraca także uwagę na pewne implikacje społeczno-polityczne wynikające ze zmian administracyjnych zachodzących w tej centralnej części kraju. Generalnie zaś zachęca do wnikliwej lektury całej książki, której wysoki poziom zapewnia Autorowi poczesne miejsce wśród historyków polskiego ruchu ludowego i w historiografii dziejów najnowszych.

Dzieło J. Sałkowskiego zostało bogato zaopatrzone w tak zwany pomocniczy aparat naukowy. Bibliografia z wykazem źródeł aktowych (archiwalnych) i drukowanych oraz obszernym i wyczerpującym zestawem literatury przedmiotu (opracowania) nie tylko wzmacnia funkcje poznawcze pracy, ale też zachęca do dalszych studiów na temat Mazowsza. Indeksy nazwisk i miejscowości znacznie ułatwiają czytelnikowi odnalezienie się w gąszczu wielu wydarzeń. Dobrze dobrane fotografie pozwalają na poglądowe odniesienie się do czołowych postaci ożywiających życie społeczno-polityczne II RP na Mazowszu i efektów ich działalności. Również pod względem estetycznym prezentowana praca swoim poziomem edytorskim sprawia jak najlepsze wrażenie, co zresztą jest normą dla wydawnictw firmowanych przez MHPRL.

REC.: Kazimierz Przybysz, Z gazeta przez życie. Zygmunt Augustyński 1890-1959, Warszawa 2019

Przedstawiana praca to biografia „wybitnego dziennikarza, naczelnego redaktora «Gazety Ludowej», organu prasowego powojennego Polskiego Stronnictwa Ludowego, więźnia politycznego przełomu lat 40. i 50. ubiegłego wieku, skazanego w jednym z pierwszych stalinowskich procesów pokazowych na karę piętnastu lat pozbawienia wolności” (s. 9).

Tę piękną postać, ludowca - patrioty, wydobył ze swoistego historycznego niebytu Kazimierz Przybysz, historyk, politolog, twórczością owocnie związany z ruchem ludowym (zSL, PSL). Praca o Zygmuncie Augustyńskim 
zajmuje istotne miejsce w całym bogatym dorobku naukowym Autora. Okazuje się, że z powodzeniem może się On swoją twórczością odnaleźć nie tylko w historii politycznej i politologii, ale także w biografistyce. Całość najnowszego dzieła, poprzedzona Uwagami wstępnymi, składa się z pięciu rozdziałów merytorycznych wyodrębnionych chronologicznie z uwzględnieniem treści odnoszących się szczególnie do pracy dziennikarskiej Z. Augustyńskiego. Rozpoczyna się w końcu zaborów, trwa w II Rzeczpospolitej, podczas II wojny światowej i okupacji niemieckiej, aby pracowite życie dziennikarza „z krwi i kości” doprowadzić do czasów Polski Ludowej, z jej niechlubnym czasem totalitaryzmu stalinowskiego.

W opisanej zawiłości polskich losów odnajdziemy Z. Augustyńskiego jako człowieka honoru, patriotę wiernego agrarystycznym $\mathrm{z}$ ducha przekonaniom, iż „Chłopi wydobyci z nędzy, oświeceni, przyciągnięci do Polski i do spraw państwowych, to najwspanialszy fundament wielkości narodu i państwa" (motto książki Z. Augustyńskiego, Chtopi maszerują, Warszawa 1944).

W I rozdziale biografii ( $W$ monarchii Franciszka Józefa. Wielka wojna) uzyskamy podstawowe informacje dotyczące Z. Augustyńskiego z okresu dzieciństwa i młodości w czasach zaborów oraz I wojny światowej. Dowiemy się więc, że „urodził się 4 października I890 roku we wsi Odporyszów w ówczesnym powiecie Dąbrowa Tarnowska w wielodzietnej rodzinie dość zamożnych, jak na warunki Galicji, rolników - gospodarzy" (s. I3). Rodzice, co wówczas tworzyło tradycyjne wartości dla tej części ziem polskich, zadbali drogą wyrzeczeń o wykształcenie Zygmunta na wyższym poziomie, jak i zresztą wszystkich swoich dzieci. Talent i odpowiednie wykształcenie pozwoliło mu, już podczas nauki w gimnazjum w Krakowie, podjąć pracę dziennikarską w wychodzącym w Krakowie „Przyjacielu Ludu”, organie ówczesnego PSL. Dzięki temu od razu, od czasów pierwszych doświadczeń dziennikarskich, związał się na całe życie z chłopskim ruchem politycznym w jego zasadniczym centrowym skrzydle (od I907 r.). Mógł później podjąć studia prawnicze w Wiedniu i Berlinie, jednocześnie będąc sekretarzem posła Jana Stapińskiego (1867-1946) i klubu poselskiego PSL w austriackiej Radzie Państwa oraz wysyłając korespondencje do słynnego wychodzącego w Krakowie „Ilustrowanego Kuriera Codziennego” („IKC”) i innych pism - „Gazety Powszechnej” i „Głosu Narodu”.

Po wybuchu „Wielkiej Wojny” został zmobilizowany do armii austriackiej, ale wkrótce, od października I9I4 r. uzyskał przydział do Legionów Polskich, co istotnie zaważyło na jego przyszłym życiorysie.

Losy Z. Augustyńskiego w okresie II RP zostały przedstawione w rozdziale II (Praca dziennikarska w Polsce niepodlegtej). Jako „szczęśliwy mąż i ojciec trójki bardzo udanych dzieci" (s. 29) czas ten spędził w Warszawie. 
Tutaj też oddał się intensywnej pracy dziennikarskiej, rozwijając swój talent i pełniąc misję społeczną z nawiązaniem do ideałów związanych z ludowcowym postrzeganiem rzeczywistości i wizji przyszłej sprawiedliwej Polski. Wśród pism, z którymi związał się w tym czasie, odnajdziemy inicjatywy udane, ale też pisemka informacyjno-sensacyjne. Wydawał nawet własne: "Gazetę Poniedziałkową" (1919-1923) czy zupełnie efemeryczny „Wiek xx”. Był redaktorem naczelnym „Expressu Porannego”. Za Jego redaktorstwa nakład gazety wzrósł do Ioo tys. egzemplarzy.

Po przewrocie majowym, raczej ambiwalentnie oceniając to wydarzenie, mimo swojego legionowego rodowodu, wyraźnie nie tylko programowo, ale również politycznie „zbliżył się do ludowców” (s. 38-39). Spotykał się między innymi z przywódcami ruchu ludowego, Wincentym Witosem i Maciejem Ratajem. Solidaryzując się z czołowymi ludowcami, aresztowanymi przez władze państwa pod rządami sanacji, zrezygnował z pracy w spółce Prasa Polska, która wydawała „Express Poranny”, i tym samym zrezygnował z redagowania tej poczytnej gazety, która stała się rzecznikiem państwa autorytarnego. Nie ograniczyło to kreatywności wydawniczej naszego bohatera, który angażował się w tworzenie kolejnych tytułów prasowych, nie zaniedbując współpracy z „IKC”, do którego przesyłał korespondencje z Warszawy. Jednocześnie, w natłoku pracy dziennikarskiej, związanej jednak głównie ze sprawami wielkomiejskimi, nie zapomniał o środowisku, z którego się wywodził $i$ któremu tak wiele zawdzięczał: „W latach 30. [...] udzielał się również społecznie [...]. Był częstym gościem na polskiej wsi, bowiem wspólnie z literatem Janem Szczepańskim, aktorem Stefanem Jaraczem i poetą Stanisławem Młodożeńcem organizował tam niedzielne poranki literackie”(s. 55).

Wyjątkową postawę patriotyczną mógł Z. Augustyński wykazać podczas okupacji niemieckiej w okresie II wojny światowej. K. Przybysz ze starannością właściwą dla całej prezentowanej pracy, przedstawił to w rozdziale III (Wojna i okupacja. W Radzie Gtównej Opiekuńczej i Delegaturze Rządu RP). Jako pracownik RGO, czyli instytucji spieszącej z pomocą wysiedlonym z ziem włączonych do Rzeszy, ludności pacyfikowanej Zamojszczyzny, uchodźcom z Wołynia, redaktor miał okazję wykazania się pełnym poświęcenia zaangażowaniem na terenie powiatu warszawskiego, gdzie był członkiem ścisłego kierownictwa. Miał więc decydujący wpływ na prowadzenie akcji dożywiania dla najbiedniejszych warstw zniewolonego społeczeństwa, pomocy medycznej, materialnej itp.

Warto też zwrócić uwagę, że nie tylko nie zaniedbywał aktywności dziennikarskiej, ale nawet w warunkach konspiracji znacznie ją rozwinął, przy tym wiążąc ją już bardzo wyraziście z ruchem ludowym (konspiracyjnym SL „Roch”). Pisywał m.in. w: „Przeglądzie”, „Przez Walkę do Zwycięstwa”, „Orce” 
i „Agencji Informacyjnej Wieś”, czołowych pismach „Rocha”. Rozwinął w tym czasie przypisany sobie talent publicystyczny, ogłaszając programową broszurę polityczną Chtopi maszerują (Warszawa 1944). Rzecz ta stanowi bodaj największe osiągniecie publicystyczno-programowe Z. Augustyńskiego, sugerujące Jego ukłon w kierunku agraryzmu.

Ponadto, łącząc pracę typowo dziennikarską z aktywnością polityczną, mocno zaangażował się w działalność w strukturach Polskiego Państwa Podziemnego, między innymi w powstałym w początkach 1942 r. Departamencie Informacji i Prasy Delegatury Rządu RP oraz z ramienia SL „Roch” w składzie Komisji Opiniodawczej Politycznego Komitetu Porozumiewawczego, który stworzyły cztery partie władzy Państwa Podziemnego (oprócz SL „Roch”, Stronnictwo Pracy, Stronnictwo Narodowe i Polska Partia Socjalistyczna „Wolność - Równość - Niepodległość”).

Podczas Powstania Warszawskiego spotkała Z. Augustyńskiego wielka tragedia rodzinna. Odcisnęła piętno na dalszym Jego życiu. Tak ją opisał: „13 sierpnia 1944 r. przyprowadzono na pozycję przy ulicy Kilińskiego na Starym Mieście zdobyty na Niemcach czołg. Radość była ogromna. Wszyscy wylegli żeby zobaczyć... i wtedy nastąpił wybuch znajdującej się w czołgu miny. Wybuch był tak silny, iż szczątki ludzkie zbierano na sąsiednich ulicach. Wśród bardzo wielu ofiar był również mój syn z synową" (s. 70).

Po wyzwoleniu spod okupacji niemieckiej rozpoczął się kolejny etap życia redaktora - „najtrudniejszy okres w jego życiu zawodowym. Rozpoczęły się trudne miesiące walki” (s. 79). K. Przybysz opis tej części życiorysu swojego bohatera zawarł w rozdziale IV (Miesiace walki. Na czele „Gazety Ludowej”). Wiążąc się już zdecydowanie z agrarystyczną częścią ruchu ludowego, czyli powojennym PSL, objął on funkcje redaktora naczelnego "Gazety Ludowej” (4 XI 1945) - poczytnej i uważanej za opozycyjną wobec nowej władzy. Po latach tak charakteryzował pismo, któremu nadał wynikający z własnych doświadczeń i pielęgnowanych wartości profil programowy: „Społeczeństwo dojrzało w naszym piśmie odmienną treść, [...] nowe tony, nowe barwy i wyczuwało polskiego ducha, wolnego od obcych naleciałości. Myśli polskie płynęły ze szpalt do polskich serc, więc też znalazły w nich życzliwe przyjęcie i serdeczny odzew" (s. 93). Wyraźnie w głoszonych poglądach, także na łamach swojej gazety, nie okazywał się zwolennikiem nowego systemu sprawowania władzy, który z nazwy miał być socjalistyczny. K. Przybysz w tym względzie odnajduje dosadne i precyzyjne opinie Z. Augustyńskiego: „metody komunistyczne są równie okrutne i bestialskie jak metody hitlerowskie, [...] jedni i drudzy [...] stosują terror i okrucieństwo, ażeby ofiarę swoją obedrzeć z człowieczeństwa, sponiewierać, zdeptać jej godność ludzką, że niezwykle łatwo piękne hasła sprawiedliwości społecznej 
stają się w ramach dyktatury płaszczykiem osłaniającym każdą podłość, każde bezprawie i każdą zbrodnię" (s. 134).

Prezentując powyższe poglądy i utrzymując żywe kontakty z przywódcami PSL, stawał sięZ. Augustyński przedmiotem inwigilacji ze strony funkcjonariuszy Urzędu Bezpieczeństwa Publicznego. Ten okres jego życia został nazwany w rozdziale $\mathrm{v}-$ Lata cierpienia. Aresztowany pod byle pozorem za prezentowanie niezłomnej postawy patriotycznej, m.in. za rzekome prowadzenie działalności szpiegowskiej, został skazany na długoletnie więzienie. Odzyskał wolność u schyłku okresu stalinowskiego (Io II 1955). O ostatnich latach Jego życia informuje rozdział vi - Uschytku żcia. Schorowany i ciągle inwigilowany przez „bezpiekę” nie mógł już podjąć efektywnej działalności opozycyjnej. „Zygmunt Augustyński zmarł po długich i ciężkich cierpieniach w mieszkaniu przy ulicy Karmelickiej [w Warszawie - przyp. A.L.] w dniu 26 sierpnia 1959 roku w otoczeniu najbliższych. Odchodził jeden z mistrzów dziennikarstwa polskiego pierwszej połowy $\mathrm{xx}$ wieku, człowiek w życiu publicznym niezłomny, wierny do końca przekonaniom i zasadom moralnym, które wyniósł z rodzinnego domu w Odporyszowie: uczciwości, niezależności osobistej i uszanowania drugiego człowieka” (s. I4I). Doczekał się mocno spóźnionej rehabilitacji, najpóźniej spośród działaczy związanych z PSL i S. Mikołajczykiem, dopiero na progu III RP (Wyrok Izby Wojskowej Sądu Najwyższego z dn. Is stycznia i99I r.).

W ostatniej części pracy - Zamiast zakończenia - Autor opisuje drogę prowadzącą do pośmiertnej rehabilitacji Z. Augustyńskiego, sytuację jego najbliższych i optymistycznie konstatuje, iż „życiem tętni Ojcowizna Zygmunta Augustyńnkiego w Odporyszowie, obecnie w powiecie tarnowskim” (s. I49).

Całość publikacji uzupełniają starannie opracowane Aneksy zawierające materiały prasowe, które doprowadziły do bezprawnego skazania Z. Augustyńskiego wyrokiem z dnia 6 VIII 1947 r.

\section{REC.: Piotr Szymanek, Droga do wolności. Wspomnienia z lat I895-1945, pod} red. naukową J. Gmitruka, Warszawa 2018

W problematykę prezentowanej książki rzeczowo wprowadza Przedmowa autorstwa redaktora naukowego, który docenił rolę syna Piotra Szymanka - Jerzego - w przygotowaniu do druku wspomnień „niekwestionowanego przywódcy ludowców ziemi łódzkiej i męża stanu w skali ogólnokrajowej" (s. 8).

Wspomnienia swoją treścią wypełniają istotnie i w przeważającej objętości, poza jeszcze materiałami innych autorów, całość Drogi do wolności. Zapisane są, co jest nietypowe dla formy literatury pamiętnikarskiej, w drugiej 
osobie: „Pasał więc Piotrek krówki od wczesnej wiosny do żniw na miedzy, a po żniwach na ściernisku” (s. 13). Zawierają się w pięciu rozdziałach ujętych chronologicznie, od daty urodzin naszego bohatera, aż do czasów wyzwolenia kraju spod okupacji niemieckiej w i945 r., czyli w rzeczywistości zakończenia II wojny światowej i jednocześnie początków Polski Ludowej.

Rozdział I (Dzieciństwo i lata chtopięce) rozpoczyna tok narracji od narodzin Piotra „przy końcu zimy I 895 roku” w Bąkowej Górze (gmina Ręczno, pow. piotrkowski) w chłopskiej rodzinie Antoniego i Franciszki. Jako najmłodszy i jedyny syn w niezamożnej rodzinie Szymanków, dzieciństwo spędzał pogodnie, pasąc krowy i uczęszczając do czterodziałowej wiejskiej szkoły, dostępnej tylko w niektórych wsiach zaboru rosyjskiego. Wzorowe opanowanie sztuki czytania stworzyło mu podstawy do samodzielnego i nieustającego w całym Jego pracowitym życiu, dalszego zdobywania wiedzy.

Jako piętnastoletni młodzieniec udał się do Częstochowy, aby zaocznie kontynuować naukę w czteroklasowym wieczorowym gimnazjum i jednocześnie uczyć się rzemiosła w dziedzinie mechaniki. „Szkołę wieczorową ukończył, ale świadectwa czeladniczego nie otrzymał, zresztą nie bardzo dbał o to, ponieważ miał zamiar dalej się uczyć i zmienić zawód” (s. I9). I tak rozpoczął kolejny etap burzliwego życia, wpleciony w działalność polityczną, od 29 kwietnia 1920 r., gdy znalazł się w Łodzi, gdzie został aresztowany przez patrol żandarmerii carskiej, podejrzany o przynależność do ruchu socjalistycznego, który, jak wiadomo, starał się w swoich programach postulować połączenie walki o wyzwolenie narodowe z wyzwoleniem społecznym.

Okres I wojny światowej - rozdział II (Praca w Niemczech) - spędził na terenie zachodniego zaborcy, gdzie wiele wycierpiał, pracując w fabrykach przemysłu ciężkiego lub odsiadując wyroki w aresztach i więzieniach. Po wielu peregrynacjach, u progu odzyskiwanej niepodległości, udało mu się wreszcie wrócić do Bąkowej Góry, do domu rodzinnego. Było to w końcu listopada $1918 \mathrm{r}$.

Rozdział III ( $W$ wolnej Polsce) Autor poświęcił swojej dojrzewającej aktywności politycznej w okresie II Rzeczypospolitej. Działalność tę rozpoczął od organizowania kół Polskiego Stronnictwa Ludowego (PSL) „Wyzwolenie" oraz koła młodzieży wiejskiej związanego z tą lewicową orientacją ruchu ludowego ${ }^{2}$. Pochłonęła go działalność na rzecz chłopów, rolnictwa i w ogóle realizacji nowej ludowej wizji państwa polskiego. Odnalazł się tym samym w historycznym pokoleniu chłopów polskich, któremu po

2 PSL w zaborze rosyjskim powstawała w poważnym stopniu z inspiracji Edwarda Abramowskiego, twórcy tzw. socjalizmu bezpaństwowego (kooperatywistycznego), od którego można było przejąć przekonanie, że charakter stosunków społecznych zależy od wartości moralnej jednostek i umiejętności ich współżycia w grupie społecznej. (Por. K. Biliński, Państwo wideologii politycznej Edwarda Abramowskiego, „Acta Universitatis Nicolai Copernici” 1987, Nauki Polityczne XVII, s. 4I-56. 
wywalczeniu niepodległości nie było obojętne to, jaka będzie ich ojczyzna teraz i w przyszłości: „Wieczorem w miejscowej szkole zebrała się prawie cała wieś, zebranie zagaił Piotr, w płomiennych słowach przedstawił wizję wolnej Polski, Polski demokratycznej. Na zebraniu zapanował nastrój patriotyczny i demokratyczny" (s. 49-50).

Z czasem zaangażował się już wyraźnie, blisko związany z młodzieżową organizacją ruchu ludowego, Związkiem Młodzieży Wiejskiej RP („Wici”) w realizację agrarystycznej wizji ludowej Polski, przy współpracy z socjalistami, w ramach ,jednolitej walki chłopów i robotników” z sanacją: „Przemawiał na wielu wiecach, [...] za przemówienia otrzymywał kilka razy wysokie wyroki, ale ostatecznie w Sądzie Najwyższym w Warszawie wygrywał” (s. 84).

Wojna 1939 r. (rozdział IV) otworzyła kolejny rozdział życia P. Szymanka. Z rozgoryczeniem przyjął przegraną z Niemcami. Zaangażował się w działalność konspiracyjną. U schyłku wojny jako prezes powiatowego przedwojennego SL odnalazł się w lewicowej części ruchu ludowego, ściśle współpracując z socjalistami i komunistami z Polskiej Partii Robotniczej, również jako prezes SL „Wola Ludu”. Wybór tej drogi doprowadził Go do objęcia funkcji przewodniczącego Powiatowej Konspiracyjnej Rady Narodowej (na pow. piotrkowski), jednak również na zagrożone utratą życia konfrontacje z prawicową (endecką) częścią konspiracji: „Miał Piotr w 1944 roku kłopoty nie tylko z Niemcami, ale i ze swoimi Polakami. Niedaleko od Ręczna był duży majątek Potockich, a jeden z Potockich był ważną figurą w Narodowych Siłach Zbrojnych. [...] Komendanci NSz, często kwaterowali u administratora majątku [...], wiedzieli o działalności Piotra. Postanowili go zlikwidować” (s. 97).

Wierny lewicowym, choć jednocześnie ludowcowym poglądom, ukształtowanym w PSL „Wyzwolenie” i „Wiciach”, znalazł się P. Szymanek $W$ Polsce Ludowej (rozdziałV) pełen zapału do kontynuowania walki o demokrację, sprawiedliwość społeczną i równouprawnienie chłopów. Działał przede wszystkim na szczeblu administracyjnym - w województwie łódzkim i powiecie piotrkowskim. Rok 1945 stał się dla Niego cezurą otwierającą ty tułową „wolność". Uważał, że również w nowych warunkach ustrojowych, poniekąd narzuconych tzw. porządkiem pojałtańskim, Polska pozostaje niezmiennie Jego ojczyzną. Świadomie wybrał drogę pozytywistycznego zaangażowania się po stronie odbudowy, a właściwie nowej drogi, która w ramach sojuszu chłopsko-robotniczego miała spełniać oczekiwania Polaków, w większości chłopów i mieszkańców wsi bądź robotników i mieszkańców miasta, w olbrzymiej przewadze pochodzenia wiejskiego. Nie podjął więc, jak niektórzy z bliskich $\mathrm{Mu}$ w działalności konspiracyjnej żołnierze Batalionów Chłopskich i Armii Krajowej, z istoty romantycznego przeciwstawienia się prowadzącego ku wojnie domowej, porządkom nowego ustroju. 
Zdając sobie sprawę, że ruch ludowy po II wojnie światowej i okupacji niemieckiej znalazł się w rozbiciu, cieszący się dużym autorytetem w tym środowisku P. Szymanek zachęcał do współpracy, uważając, iż „tylko w jedności możemy coś znaczyć" (s. II7).

Bardzo ważnym dla zrozumienia wyborów ideowo-politycznych P. Szymanka i w ogóle Jego wspomnień doprowadzonych do początków Polski Ludowej jest kompetentnie opracowany przez J. Gmitruka życiorys naszego bohatera Piotr Szymanek (I895-1975), ps. „Semko”, „Piotr” obszernie załączony do Drogi do wolności. W dacie urodzin P. Szymanka Autor odnalazł symboliczne skojarzenie z początkami polskiego ruchu ludowego, który również narodził się w I895 r. (28 lipca w Rzeszowie). Zapewniało to P. Szymankowi, niejako z góry, dozgonny kontakt podmiotowy z „nowoczesnym” ruchem politycznym Polaków.

J. Gmitruk osobno zwrócił uwagę na dokonania P. Szymanka u progu Polski Ludowej. Podkreślił, iż „działał na rzecz «rozładowania lasu», usiłując przekonać żołnierzy poakowskiej partyzantki do zaprzestania walki” (s. I30). Ponadto, „w latach 1947-1950 pełnił funkcję wojewody łódzkiego. Dzięki jego wsparciu i pomocy do końca 1949 r. na Ziemie Odzyskane z woj. łódzkiego wyjechało 378 tys. osób. Wśród osadników 50\% stanowili mieszkańcy wsi" (s. 130).

Wartość poznawczą książki istotnie uzupełnia zamieszczony w następnej kolejności tekst o „ruchu ludowym w powiecie sieradzkim w okresie «odwilży popaździernikowej (1956-1958)»” autorstwa cenionego historyka z U£, profesora Leszka Olejnika. Ten naukowy artykuł, oparty na wyczerpująco dobranym materiale źródłowym (głównie źródła archiwalne i prasowe oraz starannie wykorzystana literatura przedmiotu), daje możliwość porównawczego odniesienia dziejów ruchu ludowego w powiecie piotrkowskim do całego województwa łódzkiego, w którym P. Szymanek ponownie, po prześladowaniach w okresie stalinowskim, włączył się intensywnie - w odnowiony nurt życia politycznego. Po powrocie do Zjednoczonego Stronnictwa Ludowego, został prezesem Zarządu Wojewódzkiego i pełnił też funkcję przewodniczącego Prezydium Wojewódzkiej Rady Narodowej w Łodzi oraz posła na Sejm PRL.

Jak przekonująco stwierdził Autor prezentowanego tekstu, „na fali «popaździernikowych » zmian politycznych wielu autentycznych działaczy ludowych, odsuniętych od aktywnej działalności w poprzednich latach, bądź zepchniętych na margines życia publicznego, włączało się do działalności w ZSL. Te zarysowane wyżej tendencje nie ominęly ziemi tódzkiej” (s. 147-I48).

Kolejny, niewielki objętościowo tekst, zamieszczony w Drodze do wolności, jest autorstwa znanego dziennikarza piotrkowskiego Jerzego 
Kisson-Jaszczyńskiego. Został zaczerpnięty z Alfabetu piotrkowskiego, modnej w najnowszej literaturze formy wypowiedzi, zawierającej osobiste refleksje Autora na temat znanych postaci życia społecznego, pozytywnie lub negatywnie, a nawet obiektywnie charakteryzowanych.

Biogram poświęcony P. Szymankowi, w przeciwieństwie do kilku innych, jest w swoim wyartykułowaniu zdecydowanie pozytywny wobec tej postaci. Charakteryzuje Go jako działacza społeczno-politycznego obdarzonego szczególną charyzmą, jako swoistą „żywą legendę”, ale jednocześnie człowieka „z krwi i kości”, który nigdy „nie stronił od dobrego towarzystwa, od umiłowanego łowiectwa” (s. 170). Sam dziennikarz miał okazję odnalezienia się w kręgu towarzyskim byłego już wówczas wojewody. Z Jego inspiracji, jak przyznaje: „wstyd powiedzieć, padł mój rekord picia. Cały czas dobrze «zakąszając», wypiłem jeszcze... dwunastą [«półmusztardówkę» - przyp. A.L.]” (s. 167).

Treść książki istotnie uzupełnia kolejny tekst J. Gmitruka: Jubileusz Jerzego Szymanka. Dzięki temu całość stała się nie tylko symbolicznym hołdem złożonym P. Szymankowi, ale także Jego synowi, także wielce zasłużonemu działaczowi ruchu ludowego z okresu PRL oraz czasów transformacji ustrojowej do III Rzeczypospolitej.

Obie te postacie zespalały swoją aktywnością - tak w czasie wojny, jak i pokoju - pokolenia historyczne Polaków XX w. zabiegających o demokratyczną i rozwiniętą cywilizacyjnie ojczyznę. Starały się to czynić z uwzględnieniem położenia geopolitycznego naszego kraju oraz tradycji polskiego ruchu ludowego. To więc Ich łączyło jako wspólny system wartości. Syn od dzieciństwa uznawał autorytet Ojca, wypełniając Jego wskazówki i inspiracje w swoim dorosłym życiu. Zabiegał o zachowanie wdzięcznej pamięci o Ojcu dla kolejnych pokoleń. Pamięć tę do niedawna pielęgnowała Szkoła Podstawowa w Ręcznie (pow. piotrkowski), której 30 sierpnia 1980 r. nadano imię Piotra Szymanka.

Jerzy (ur. II IV 1937), podobnie jak Ojciec „wrażliwy na ludzką krzywdę i dochodzenie prawdy" (s. I80), swoim przykładnym życiem społeczno-zawodowym starał się, w nowych warunkach ustrojowych i co za tym idzie oświatowych, spełniać nadzieje Ojca. Po ukończeniu studiów dziennikarskich w Uniwersytecie Warszawskim podjął pracę w prasie ruchu ludowego („Dziennik Ludowy”, „Zarzewie”). Następnie rozpoczął wielce owocną działalność społeczno-polityczną w tymże ruchu ludowym. Był m.in. prezesem Wojewódzkiego Komitetu ZSL w Łodzi, sekretarzem

3 Szkoła ta została pozbawiona patrona zarządzeniem administracyjnym Wojewody Łódzkiego Zbigniewa Raua, zob. Dziennik Urzędowy Wojewody Łódzkiego, 2 marca 2019. 
Naczelnego Komitetu zSL, wiceprezesem NK zSL. Ponadto, sprawował kilkukrotnie mandat posła. Był sekretarzem Rady Państwa (1983-1985), prezesem Centralnego Związku Spółdzielni Rękodzieła Ludowego i Artystycznego „Cepelia”, dyrektorem generalnym w Kancelarii Sejmu i szefem gabinetu Marszałka Sejmu, itd. Odegrał zasłużoną rolę w opracowaniu i przyjęciu Konstytucji RP z 1997 r.

Na Jubileuszu 80. rocznicy urodzin J. Szymanka, przebiegającym jednocześnie z uroczystym spotkaniem posłów i senatorów z okazji 20. rocznicy uchwalenia Konstytucji (8 IV 2017), życzenia Jubilatowi złożył m.in. dyrektor MHPRL, dr J. Gmitruk, wyrażając „uznanie i najwyższy szacunek dla [...] wieloletniej aktywności i osiągnięć w pracy społeczno-politycznej dla dobra Ojczyzny - Polski, wsi i ruchu ludowego" (s. 179).

Lekturę wydawnictwa, które ma szansę pogłębienia wiedzy szerokich rzesz czytelników o zasługach i dramatycznej drodze chłopów polskich do lepszej Polski, znacznie uatrakcyjniają starannie dobrane fotografie, zaś uwiarygadniają aneksy, bibliografia przedmiotowa i indeks nazwisk.

\section{REC.: Jan Hebda, Ze wsi do historii. Zarys życia i dziatalności Wiestawa Wody. 1946-2010, Warszawa 2019}

Prezentowane opracowanie to interesująca i jednocześnie pouczająca biografia ideowego ludowca z Małopolski, regionu będącego niejako kolebką całego ruchu ludowego, od końca XIX w. pielęgnującego pamięć o tak wybitnych tego ruchu animatorach, jak choćby Wincenty Witos i Jakub Bojko. Z kart książki przenika do czytelnika postać czysta w działaniach społecznych, pracowita w rozumieniu pozytywistycznym i nawiązująca do idei oraz tradycji młodzieżowej części ruchu ludowego, czyli ZMW RP „Wici”. Owocnie rozwijającą się aktywność tego człowieka na rzecz wsi i w ogóle przeobrażeń społeczno-gospodarczych Polski, realizowaną na przełomie Polski Ludowej i III Rzeczypospolitej, przerwała tragiczna katastrofa samolotu rządowego (Io IV 20IO), w którym jako oficjalny przedstawiciel Klubu Poselskiego PSL leciał na „uroczystości katyńskie”.

Książkę napisał Jan Hebda, szerzej znany i doceniany w historiografii jako autor opracowania o historii urzędów sołtysa i wójta w Polsce. Biografia Wiesława Wody oparta została na starannie i wszechstronnie dobranym materiale źródłowym. Tok narracji ożywiają udanie wykorzystane źródła wywołane w postaci zebranych przez Autora kilkudziesięciu wywiadów z osobami współpracującymi z W. Wodą i oceniającymi z uznaniem Jego dokonania.

4 J. Hebda, Z soltysem i wójtem przez wieki, Warszawa 2016. 
Tak jak w klasycznych pracach biograficznych, układ prezentowanej publikacji jest chronologiczny, a właściwie chronologiczno-problemowy. Prowadzi opis życia bohatera, od urodzenia do tragicznej śmierci, zwracając uwagę w poszczególnych częściach opracowania na najbardziej zasadnicze jego działania, przede wszystkim w sferze społeczno-zawodowej i politycznej, poza rozdziałem I (Rodowód, lata nauki i początek samodzielnego życia), który został poświęcony w przewadze życiu rodzinnemu.

Właśnie w rozdziale I, przedstawiając dzieje chłopskiego rodu Wodów, Autor zwrócił uwagę, że Wiesław, urodzony 17 VIII 1946 r. we wsi Poleśnica, reprezentował pierwsze pokolenie powojenne biednej chłopskiej rodziny, w której wychowywało się ośmioro dzieci. Od wczesnej młodości „w praktyce poznał blaski i cienie pracy na roli, a zdobyta tą drogą wiedza i umiejętności okazały się przydatne, gdy już ze szczebla władzy zajmował się m.in. rolnictwem. Zdobyte później wyższe wykształcenie rolnicze umożliwiło mu systemowe podchodzenie do tego działu gospodarki narodowej. Natomiast wpisana w dziecięco-młodzieżowy okres jego życia praktyka pozwoliła lepiej zrozumieć specyfikę rozdrobnionego rolnictwa małopolskiego" (s. 26).

Zdobywając drogą wyrzeczeń i wrodzonej pracowitości kolejne szczeble wykształcenia aż do wyższego rolniczego, wydostawał się z rodzinnej wsi, w której raczej nie miał perspektyw rozwoju, na szerokie tory zagadnień społeczno-politycznych Małopolski i całego kraju. Przy tym nie tracił związku z wsią ani dumy z własnego pochodzenia, zaś nade wszystko pragnął efektywnie działać na rzecz wydobycia swojego środowiska z zacofania cywilizacyjnego, doświadczanego od czasów poprzednich za sprawą szlachty, mieszczaństwa i rządzących. Projekcja programowa Polski Ludowej, zapoczątkowana reformą rolną z września 1944 r., bezpłatna oświata i służba zdrowia, zachęcały młodzieńca pochodzącego z małorolnej wsi do podjęcia aktywności społeczno-zawodowej na rzecz wsi w ramach ustroju, który mógł się jednak okazać utopią społeczną.

Pierwszą aktywność społeczną podjął podczas studiów na Wydziale Rolnym Wyższej Szkoły Rolniczej w Krakowie, które ukończył w 1969 r. Działał na szczeblu wydziałowym, uczelnianym i okręgowym w Związku Młodzieży Wiejskiej (zMw), młodzieżowym zapleczu ruchu ludowego, nawiązującym do tradycji „wiciowych”. Mógł po studiach, zatrudniony na etacie asystenta-stażysty, rozpocząć karierę naukową, jednak jako człowiek czynu i zwolennik praktycznego działania wolał swoją aktywność społeczno-zawodową skierować bezpośrednio w teren na wieś. W życiu i pracy wspierała Go w ciągu 33 lat niezwykle udanego związku żona Wiktoria z domu Jakubiak, pochodząca również z rodziny chłopskiej 
z niedalekiej Kasinki Małej, absolwentka Wyższej Szkoły Ekonomicznej (obecnie Uniwersytet Ekonomiczny) w Krakowie.

Kolejne części prezentowanej książki dotyczą aktywności zawodowej i społeczno-politycznej naszego bohatera. I tak rozdział II (Przedtarnowski etap życia i pracy Wiestawa Wody) przyniósł chronologiczne zestawienie informacji o jego pierwszych poczynaniach zawodowych i pierwszych funkcjach w organizacjach społecznych prowadzących do pełnej dojrzałości politycznej i obejmowania wysokich stanowisk w tzw. aparacie władzy Małopolski i Krakowa. Do awansów w Polsce Ludowej (do 1989 r.) uzyskiwał rekomendacje ze strony zSL, czyli tzw. partii sojuszniczej w ramach systemu partyjnego z kierowniczą rolą Polskiej Zjednoczonej Partii Robotniczej. Potrafił wówczas, z pożytkiem dla swojego środowiska i własnego ruchu politycznego, działać tak, aby zbytnio nie ulegając naciskom ustrojowego hegemona, zadbać o interesy wsi i rolnictwa.

Przejście do praktyki zawodowej rozpoczął, po rocznym stażu w wSE, od uzyskania etatu nauczycielskiego w podkrakowskim Czernikowie w Państwowym Technikum Rolniczym w 1970 r. (na stanowisku nauczyciela mechanizacji rolnictwa) i następnie będąc wizytatorem w nadzorze oświatowym krakowskiego Oddziału Oświaty Rolniczej. Później, oddelegowany do pracy etatowej w ruchu młodzieżowym, rozpoczął w nim szybką karierę, obejmując funkcję wiceprzewodniczącego Zarządu Wojewódzkiego Związku Socjalistycznej Młodzieży Wiejskiej (CZSMw) w Krakowie w 1974 r.

Po likwidacji na skutek reformy administracyjnej „dużego” województwa krakowskiego w 1975 r. został prezesem Wojewódzkiego Związku Kółek Rolniczych w nowym województwie, co jak się wydaje, bardziej odpowiadało Jego kompetencjom i temperamentowi działacza. Kierując tą organizacją $\mathrm{w}$ terenie i ciągle bogacąc swoją wiedzę (m.in. Studium Doskonalenia Kadr Kierowniczych w AE - lata 1986-1987), stał się wysokiej klasy specjalistą w zakresie polityki rolnej.

Udzielał się w samorządzie terytorialnym. Jako radny Miejskiej Rady Narodowej w Krakowie (od 1976) u schyłku PRL objął stanowisko wiceprezydenta Krakowa, natomiast w początkach III RP z ramienia PSL (I990I99I) - wicewojewody krakowskiego. Gdy został posłem do Sejmu (tzw. kontraktowego), brał udział w powołaniu Agencji Własności Rolnej Skarbu Państwa (AWRSP) - ta przejęła grunty Państwowych Gospodarstw Rolnych - i Państwowego Funduszu Ziemi. Został nawet kierownikiem ekspozytury krakowskiej tej instytucji (lata 1992-1994).

Rozdział III pracy (Blaski icienie okresu wojewodowania) Autor w całości poświęcił dokonaniom W. Wody jako wojewody tarnowskiego, przedstawiciela administracji państwowej w stosunkowo młodym województwie, istniejącym 
od reformy z I Vi I975r. 5 Sprawował tę funkcję z powodzeniem dla rozwoju tej jednostki administracyjnej w ciągu prawie czterech lat od $1994 \mathrm{r}$. Zanotował na swoim koncie szczególne osiągnięcia w opiece nad samorządem terytorialnym, służbą zdrowia, rolnictwem i kulturą jako organizator dorocznej imprezy Światowe Forum Mediów Polonijnych w Tarnowie.

W rozdziale IV (Ludowiec i parlamentarzysta) Autor opisał dwa zasadnicze wątki społecznej aktywności bohatera swego dzieła, przy tym wyjątkowo długie i absorbujące w całości jego dokonań na rzecz środowiska wsi, regionu i państwa.

Po pierwsze, przez całe swoje życie od czasów młodzieńczych, prawie 42 lata, funkcjonował aktywnie w ruchu ludowym, przy tym w różnych formacjach, od ruchu młodzieżowego (ZMW, ZSMW), poprzez ruch spółdzielczy i zawodowy (kółka rolnicze), ochotnicze straże pożarowe, aż po dojrzały ruch polityczny - partie polityczne (zSL, PSL). Pełnił w nich funkcje odpowiedzialne, twórcze, wymagające pełnego zaangażowania, a nawet poświęcenia; od instancji podstawowych, poprzez regionalne, aż do centralnych. Zwieńczył tę aktywność niemal dziesięcioletnim przewodzeniem małopolskiej instancji PSL - prezes Wojewódzkiego Komitetu od roku 1999 do śmierci. Na swoim terenie udanie przeprowadził referendum, na mocy którego Polska uzyskała legitymację społeczną do tego, aby od I maja 2004 r. stać się pełnoprawnym członkiem Unii Europejskiej.

Po drugie, swoistą misję wobec środowiska wiejskiego wypełniał jako wieloletni parlamentarzysta, początkowo w Polsce Ludowej z rekomendacji zsL, później w III RP z list wyborczych PSL; najpierw w systemie plebiscytowym realnego socjalizmu, później w wolnych wyborach systemu liberalno-demokratycznego. W czasie transformacji ustrojowej przyczynił się w pewnym stopniu do płynnego przeprowadzenia ruchu ludowego z PRL-u do III RP i zachowania godności przez ten ruch w nowych ustrojowo warunkach.

W wyborach do Sejmu III kadencji w 1997 r., po pewnej przerwie, został ponownie posłem i jako zawodowy parlamentarzysta sprawował tę funkcję do śmierci. Był aktywny m.in. jako wiceprzewodniczący komisji sejmowych, głównie Komisji Samorządu Terytorialnego i Polityki Regionalnej oraz Komisji Administracji i Spraw Wewnętrznych. Nie tracił kontaktu ze swoim okręgiem wyborczym: „Na poselskie dyżury do biura w Tarnowie najczęściej przyjeżdżał z Krakowa pociągiem. Na tarnowskim dworcu czekał już na niego dyrektor biura Marczyk, a po wejściu do jego pomieszczeń dzień pracy zaczynał się od sakramentalnej wręcz formuly: «Zbyszek, po

5 Województwo tarnowskie „obejmowało $415 \mathrm{I} \mathrm{km} \mathrm{km}^{2}$, liczyło 48 jednostek samorządowych, w tym 3 miasta, 6 jednostek miejsko-wiejskich i 39 gmin wiejskich. Mieszkało w nim 696 tys. osób, w tym $64 \%$ mieszkańców wsi” (s. II2). 
maluchu, kawusię i do roboty». Po tym wstępie przyjmował umówionych interesantów, zaś ja [Jan Hebda - przyp. A.L.] sporządzałem stosowne notatki i następnie redagowałem odpowiednie wystąpienia posła, nadając sprawom urzędowy tok. Poseł zaś po zakończeniu dyżuru często wychodził do różnych instytucji, w tym i do lokalnych rozgłośni” (s. I80).

W ostatnim, v rozdziale pracy (Inne formy i przejawy dziatalności Wiestawa Wody) Autor, jako bliski współpracownik posła, wymienia, nie trzymając się ściśle podejścia chronologicznego, inne ważne z punktu widzenia całości Jego dokonań dziedziny aktywności. Stara się je umieścić, zresztą udanie i przekonująco, w aksjologicznej triadzie sformułowanej przez młodszego brata W. Wody, Andrzeja, który stwierdził: „Najważniejsze w jego życiu były trzy rzeczy: rodzina, polityka i pszczoły" (s. 185). Do tego należy też dodać ochotnicze straże pożarne. Strażom uważanym zresztą za część ruchu ludowego oddawał serce i czas wolny. Pełnił w nich funkcje wiceprezesa i prezesa na szczeblu woj. krakowskiego od 2009 r. do śmierci.

Nasz bohater, co podkreśla Autor książki, z dużym zaangażowaniem zajmował się pszczelarstwem. W rodzinnej wsi żony pielęgnował niewielką pasiekę, zaś w interpelacjach poselskich podejmowal kwestie związane z ochroną i możliwościami rozwoju pszczelarstwa w Polsce.

Biografia skromnego działacza ruchu ludowego z Małopolski, w napisanie której Jego kolega i współpracownik J. Hebda włożył wiele żmudnej pracy źródłowej, zaopatrzona jest na koniec w refleksję: „Dla nikogo nie ulega wątpliwości, że nagła śmierć Wiesława, tak dramatycznie przeżyta przez rodzinę, była również tragedią dla ogółu ludowców i strażaków. Godząc się z tym faktem, bo przecież nie ma innego wyjścia, należy jednak podkreślić, że należy mu się poczesne miejsce w licznej osobowo galerii wybitnych małopolskich ludowców" (s. 205).

Starannie dobrany materiał zdjęciowy w postaci fotografii rodzinnych i archiwalnych dobrze ilustruje poszczególne etapy życia W. Wody.

\section{REC.: Janusz Gmitruk, Chtopskie oficyny spótdzielczego i obywatelskiego dziata- nia, Warszawa 2019 (w jubileusz siedemdziesięciolecia Ludowej Spół- dzielni Wydawniczej)}

Powszechnie ruch ludowy kojarzy się z funkcjonowaniem partii politycznych (stronnictw) i co najwyżej, jeszcze z działalnością zorganizowaną młodzieży wiejskiej. Tymczasem ten ruch społeczny, będący przejawem nie tylko politycznych, ale także społeczno-kulturalnej i gospodarczej aktywności wsi polskiej, mieścił w sobie również aktywność takich organizacji społecznych, jak m.in. kół gospodyń wiejskich, ochotniczych straży po- 
żarnych i kółek rolniczych, zrzeszeń sportowych, stowarzyszeń dziennikarskich. W całości podporządkował swoje działania ideom postępu społecznego, charakterystycznym, chociaż różnie programowo ukierunkowanym, dla ruchów $\mathrm{w}$ istocie reformatorskich występujących z pozycji centro-lewicowych i centrowych na scenie politycznej.

W ponadstuletniej aktywności ruch ludowy, zachowując egalitarny charakter, nie zhańbił się działaniami aspołecznymi bądź niepatriotycznymi. Zapewne dlatego, że od początku działania, jeszcze pod zaborami, walcząc o odzyskanie niepodległości, jednocześnie zabiegał o tzw. równy start dla młodzieży najbardziej pokrzywdzonej w dziejach warstwy społecznej, czyli chłopów. Równy start powinien zależeć nie od przewag materialnych (majątku), ale od powszechnego i równego dostępu do wiedzy (wykształcenia), które młode pokolenie mogłoby wykorzystać dla rozwoju cywilizacyjnego większości naszego społeczeństwa i zbudowania demokratycznych podstaw przyszłego ludowego państwa. Nie bez powodu więc swoje rozważania jubileuszowe o chłopskich oficynach wydawniczych J. Gmitruk poprzedził mottem zaczerpniętym z programu Związku Młodej Polski Ludowej ogłoszonego na terenie zaboru rosyjskiego w styczniu 1907 r.: „Dostojeństwo ludu jeno z oświaty przyjść może”.

Samego Autora prezentowanej pracy sympatykom ruchu ludowego, jak i szerszej opinii publicznej, nie trzeba specjalnie przedstawiać. Bez Jego aktywności społeczno-zawodowej i towarzyszącej temu twórczości trudno sobie wyobrazić tak olbrzymi rozrost historiografii tego nurtu, jakże pożytecznej dla budowania świadomości historycznej Polaków doby współczesnej.

W wielowątkowej aktywności ruchu ludowego należy zwrócić uwagę na to, że poprzez publikacje i upowszechnianie wiedzy przy pomocy druku, ruch ten mógł wszechstronniej realizować swoje posłannictwo społeczne; mógł dać szansę chłopskiej wsi na wyjście z ciemnoty intelektualnej i tym samym wprowadzać, szczególnie młodzież, w obręb zainteresowań podmiotowych państwa oraz dawać jej możliwość świadomego i ukierunkowanego kreowania losów swoich, regionu (wsi, „małej ojczyzny”) i ojczyzny. Miał tego świadomość wybitny Polak, ludowiec i mąż stanu Wincenty Witos, współtwórca odzyskanej w I9I8 r. państwowości, który stwierdził, że „obywatel, który nie czyta pism rozumnych, wpada mimo woli w mrok nieświadomości” (s. 7).

Książka autorstwa J. Gmitruka ma charakter publikacji popularnonaukowej. Nie znaczy to, że nie cechuje jej wysoki poziom merytoryczny. Zapisana jasnym i potoczystym językiem, odwołuje się do dotychczas ogłoszonych drukiem nielicznych opracowań, ale też do materiałów źródłowych, archiwalnych i drukowanych. Posiada logiczny i przejrzysty układ ujęty rzeczowo i chronologicznie. 
Po Przedmowie, niejako ustawiającej metodologicznie treść i znaczenie opracowania, Autor podjął się syntetycznego przedstawienia początków ludowcowej działalności wydawniczej. Uczynił to w pierwszej części - Przez lud dla ludu. Zaznaczył, że spośród rozproszonych jeszcze pod zaborami różnych inicjatyw edytorskich, które dokładnie wymienia, na uwagę zasługuje powołanie 4 XII I9I3 r. Ludowego Towarzystwa Wydawniczego jako spółdzielni wydającej pismo „Piast” poświęcone „sprawom ludu polskiego”. Był to tygodnik, póki co, publikowany na terenie zaboru austriackiego. $Z$ kolei w zaborze rosyjskim dzięki aktywności PSL „Wyzwolenie” utworzona została Ludowa Spółdzielnia Wydawnicza (28 I 1918).

W następnej części pracy, Wniepodlegtej Polsce, Autor przedstawił szereg wydawnictw spółdzielczych, firmowanych przez podzielony (przynajmniej do I93 I r.) ruch ludowy, który mimo podziałów, we wszystkich swoich stronnictwach realizował hasło: „Ziemia, oświata, władza dla ludu”. W tym miejscu warto zwrócić uwagę na próby zintegrowania po przewrocie majowym w 1926 r. i przejściu do opozycji nie tylko całego rozproszonego w trzech przynajmniej partiach ruchu ludowego, ale także wydawnictw tych partii. Dlatego w kwietniu I93I r. Naczelny Komitet Wykonawczy SL powołał najpierw Spółkę Akcyjną, a następnie przekształcił ją I września tegoż roku w Spółdzielnię Wydawniczą „Prasa Ludowa”, która jednak ograniczyła działalność do wydawania od 1933 r. tygodnika „Zielony Sztandar”. Osobną Ludową Spółdzielnię Wydawniczą prowadzili od marca 1932 r. działacze SL w Wielkopolsce. Efemerydą było utworzenie w 1932 r. Spółdzielni Wydawniczej „Wici”.

Jest również w prezentowanej pracy pewna informacja, którą można uznać za dotychczas bliżej nierozpoznaną ciekawostkę. Dotyczy dziejów przedwojennego Łódzkiego ZMW RP („Wici”). Działacze tej autonomicznej w ruchu wiciowym instancji wojewódzkiej 27 XII 1934 r. we wsi Busina (pow. sieradzki) wyszli z zamiarem powołania Spółdzielni Wydawniczej „Prasa Chłopska”. Ostatecznie formalnie została powołana 29 X 1935 r. Firmowała ukazujące się - dzięki staraniom najbardziej lewicowej w „Wiciach” tzw. grupy poznańsko-łódzkiej - pismo „Chłopskie Życie Gospodarcze”. Prześladowana przez cenzurę sanacji nie ograniczała się do firmowania tego pisma, albowiem nakładem Spółdzielni ukazał się też słynny pamiętnik Kazimierza Deczyńskiego Opis życia wieśniaka polskiego (przedmowa Stefan Ignar), a także poemat Wojciecha Skuzy Fornale i utwór sceniczny dla amatorskich teatrów ludowych Zofii Solarzowej Koszulka.

Nowych jakości podporządkowanych przede wszystkim walce o wyzwolenie narodowe nabrała działalność ruchu ludowego (sL „Roch”) W latach wojny i okupacji (tytuł kolejnego rozdziału). Z chwilą wybuchu wojny została przerwana działalność wszystkich oficyn „na okres kilku lat. Ostatni 
numer «Piasta» Wydawanego przez Ludowe Towarzystwo Wydawnicze «Piast» w Krakowie wydrukowano z datą 3 września 1939 roku” (s. 37). Mimo wszystko, choć zagrożona przez okupanta najwyższą karą, działalność wydawnicza prowadzona była dość żywiołowo, często jedynie w środowiskach lokalnych. Niemniej, ukazywały się również broszury i centralne pisma ruchu ludowego. Pierwszym z nich był „Przegląd” wydawany nieregularnie jako miesięcznik i tygodnik.

Pod koniec okupacji, w maju I944 r., w Wiśniewce (Podlasie), udało się jednak powołać tajną Spółdzielnię Wydawniczą „Płomienie”. Powstała, aby swoimi wydawnictwami wspomóc tajną oświatę, z inicjatywy działaczy SL „Roch” i Batalionów Chłopskich, m.in. Heleny Brodowskiej (po wojnie profesor U£, historyk wsi i ruchu ludowego). „Płomienie” wydały dziesięć skryptów dla zakonspirowanej Wolnej Wszechnicy Polskiej.

W kolejnym rozdziale $W$ nowej Polsce (1945-1949) Autor przedstawił inicjatywy wydawnicze powojennych partii ruchu ludowego rozproszonych w ramach prosocjalistycznego SL i agrarystycznego PSL. Tuż przed kolejnym zjednoczeniem ruchu ludowego pozostały na rynku wydawniczym dwie oficyny: związana z PSL Spółdzielnia Wydawnicza "Chłopski Świat” i z SL - Spółdzielnia Wydawnicza „Słowo Ludowe”.

Jak słusznie podkreślił Autor, zjednoczenie ruchu ludowego i powstanie Zjednoczonego Stronnictwa Ludowego (zSL) istotnie wpłynęło na powstanie i poziom działalności największego i posiadającego największy dorobek wydawnictwa tego ruchu politycznego. Dnia 7 października 1949 r. na posiedzeniu Komisji Jedności Ruchu Ludowego podjęto uchwałę o połączeniu wymienionych placówek. Dzięki temu Rada Ministrów ówczesnego rządu podjęła uchwałę o powołaniu Ludowej Spółdzielni Wydawniczej (LSW).

Dorobek tej wyjątkowej oficyny jest zaiste imponujący. Spółdzielnia rozwinęła skrzydła szczególnie w czasach po tzw. odwilży popaździernikowej, konkretnie od drugiej połowy lat 60. Xx w. Do końca Polski Ludowej mieściła się swoimi dokonaniami, poziomem i znaczeniem (zarówno pod względem liczby tytułów, jak i wielkości nakładów) w połowie pierwszej dziesiątki polskich wydawnictw. Jako wydawnictwo pełnoprofilowe wydawała książki ze wszystkich dziedzin piśmiennictwa. Trudno jest w krótkim tekście zaprezentować najważniejsze dokonania tej placówki; były to przede wszystkim działa udostępniające wiedzę o wsi polskiej, jej tradycjach, kulturze, autorytetach, przemianach społecznych, walce o wolność narodu i emancypację. Łączny nakład książek wydanych przez LSW w latach 1949-2019 przekroczył $75 \mathrm{mln}$ egzemplarzy. Autor, a my razem z nim, pochylamy się z uznaniem na kilku głośnych, spośród wielu uznanych ogólnospołecznie, dokonaniach oficyny, w której „ukazywały się publikacje [...] w różnorod- 
nych tematycznie seriach i cyklach wydawniczych, obejmujących: aktualne problemy wsi i kraju, «Bibliotekę Myśli Ludowej», «Bibliotekę Uniwersytetów Ludowych», wspomnienia dowódców i żołnierzy BCh, pamiętniki działaczy chłopskich i młodzieży, w tym serię wznowień klasycznych pamiętników chłopskich, serię ekologiczną, cykl biograficzny w dwóch wersjach - o wybitnych ludziach kultury i nauki oraz przywódcach ruchu ludowego, «Bibliotekę Poetów», serię tomików poetów ludowych, baśnie i podania ludowe, gawędy współczesne, opowieści przyrodnicze, prozę inspirowaną tematami z życia dzieci wiejskich, «Bibliotekę Ludową » - serię laureatów Nagrody Nobla. W dorobku wydawniczym Ludowej Spółdzielni Wydawniczej wyodrębniają się też niebędące seriami grupy konkretnych rodzajów publikacji, jak monografie historii ruchu ludowego, książki społeczno-polityczne, proza i poezja nurtu chłopskiego, krytyka literacka. W obszernym dziale publikacji poświęconych kulturze ludowej i folklorowi wyróżniały się Dzieta wszystkie Oskara Kolberga (s. 77-78).

Wyąatkowo wysoki poziom LSW nawiązywał nie tylko do okresu sprzyjającego rozwojowi czytelnictwa i kulturze książki, Polski Ludowej, mecenatu państwa i zSL, ale również istotnie wynikał z rozumnej aktywności działaczy ludowcowych, którzy z pasją i oddaniem kierowali tą oficyną. Wśród nich na szczególne uznanie zasługuje Leon Janczak (1922-2009) kierujący placówką jako redaktor naczelny i prezes przez szesnaście lat (1973-1989). Czasy, gdy kierował LSW można uznać za lata „największego rozwoju i osiągnięć” (s. 80) Spółdzielni.

LSW przetrwała ostatecznie czas transformacji ustrojowej, ale do poprzedniej świetności już nie wróciła. Polityka rynkowa nowego ustroju politycznego okazała się bardzo niekorzystna dla niekomercyjnych instytucji wydawniczych. Niemniej jednak, dzięki pomocy edytorskiej, merytorycznej i organizacyjnej ZHRL i MHPRL, LSW nieco ustabilizowała swoją pozycję. Jak zaznaczył J. Gmitruk na koniec swego opracowania, „jest dziś jedynym z najdłużej działających wydawnictw w Polsce oraz jednym z nielicznych już spośród tych, które zachowały spółdzielczy charakter. $Z$ pewnością można ją uznać za ważny i godny uznania przykład wieloletniej formuły spółdzielczego i obywatelskiego działania w historii nie tylko polskiego ruchu wydawniczego, ale także i ludowego ruchu patriotycznego" (s. 85).

Załączone w ostatniej części pracy liczne fotografie, przeważnie unikalne, pochodzące $z$ archiwum MZPRL, znacznie wzmacniają funkcje poznawcze, podnoszą poziom estetyczny całości wydawnictwa. 